\title{
Transparentnost lokalnih proračuna na primjeru 33 hrvatska grada
}

Bronić, Mihaela; Ott, Katarina; Urban, Ivica

Source / Izvornik: Odabrani prijevodi, 2012, 3, 1 - 16

Journal article, Published version

Rad u časopisu, Objavljena verzija rada (izdavačev PDF)

https://doi.org/10.3326/op.13

Permanent link / Trajna poveznica: https://urn.nsk.hr/urn:nbn:hr:242:822617

Rights / Prava: Attribution-NonCommercial-NoDerivatives 4.0 International/ImenovanjeNekomercijalno-Bez prerada 4.0 međunarodna

Download date / Datum preuzimanja: 2023-04-26

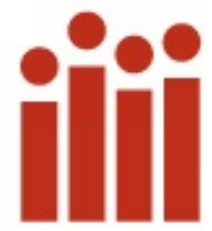

Repository / Repozitorij:

Institute of Public Finance Repository

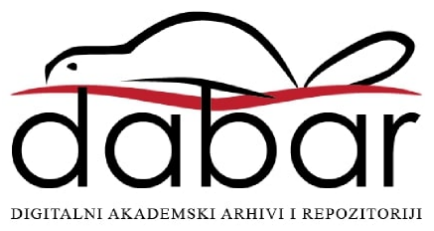


Smičiklasova 2I

Io ooo Zagreb

Tel. oI/4886-444, 4819-363

Fax oI/48I9-365

ured@ijf.hr

www.ijf.hr

\section{ODABRANI PRIJEVODI}

ISSN I847-7445

\section{BR. I3/I2}

citirati: Bronić, M., Ott, K. i Urban, I., 20I2. "Local budget transparency: the case of 33 Croatian cities". Financial Theory and Practice, 36 (4), 355-37I. http://www.ijf.hr/upload/files/file /FTP/20I2/4/bronic-ott-urban.pdf

Svi Odabrani prijevodi dostupni su na: http://www.ijf.hr/hr/publikacije/cas opisi/I2/odabrani-prijevodi/III/

\section{TRANSPARENTNOST LOKALNIH PRORAČUNA}

NA PRIMJERU 33 HRVATSKA GRADA

\author{
DR. SC. MIHAELA BRONIĆ \\ DR. SC. KATARINA OTT* \\ DR. SC. IVICA URBAN*
}

\author{
Prethodno priopćenje \\ JEL: H7O, H83 \\ UDK: 336 \\ DOI: $10.3326 /$ op. 13
}

\begin{abstract}
SAŽETAK
Mjerimo transparentnost proračuna u 33 hrvatska grada 20Io. godine, istražujući kvalitetu gradskih informacija o proračunima i otvorenost gradskog proračunskog procesa javnosti. Sastavljamo i odgovaramo na upitnik temeljem kojeg računamo Indeks otvorenosti gradskog proračuna (OCBI), koji je opća mjera transparentnosti proračuna svakog grada. Također provodimo anketu među predstavnicima izvršnih i predstavničkih tijela i organizacija civilnog društva u promatranim gradovima te među predstavnicima Ministarstva financija. Opća mjera proračunske transparentnosti - OCBI - $u$ analiziranim gradovima iznosi $u$ prosjeku $65 \%$ (kreće se od $82 \%$ do $45 \%$ ), a glavni su problemi u većini gradova povezani s lošom kvalitetom podataka u glavnim lokalnim proračunskim dokumentima. Rezultati ankete upućuju na to da postupak razmjene gradskih proračunskih dokumenata nije dovoljno transparentan.
\end{abstract}

Ključne riječi: gradovi, proračuni, proračunski proces, transparentnost, Hrvatska

"Ovaj članak proizlazi iz projekta "Measuring local units' transparency and accountability: The Croatian open local budget index" koji su sufinancirali Center on Budget and Policy Priorities (CBPP), Washington, SAD i Institut za javne financije (IJF), Zagreb, Croatia. Autori zahvaljuju CBPP-u, glavnim suradnicima na projektu (Ivanu Škocu, Marijani Bađun i Marku Primorcu) kao i dvojici anonimnih recenzenata članka. Za sve su greške i nedosljednosti odgovorni autori.

Primljeno: 28. prosinca 20II.

Prihvaćeno: 2. svibnja 2012.

Mihaela BRONIĆ

Institut za javne financije, Smičiklasova 2I, IOooo Zagreb, Hrvatska e-mail: mihaela@ijf.hr

Katarina OTT

Institut za javne financije, Smičiklasova 2I, IOooo Zagreb, Hrvatska e-mail: kott@ijf.hr

Ivica URBAN

Institut za javne financije, Smičiklasova 2I, IOooo Zagreb, Hrvatska e-mail: ivica@ijf.hr 


\section{UVOD}

Posljedica je procesa demokratizacije i fiskalne decentralizacije povećanje broja javnih dobara koja se osiguravaju na lokalnoj razini. Kako bi ta dobra mogla biti isporučivana što je učinkovitije moguće, građani trebaju razumjeti lokalne proračune i aktivno sudjelovati u lokalnom proračunskom procesu. Njime se određuje npr. koliko građani plaćaju lokalni javni prijevoz, koliko će platiti pohađaju li njihova djeca javne vrtiće ili hoće li imati javnu uličnu rasvjetu.

Ipak, unatoč iznimnoj važnosti, mnogo ljudi ne razumije lokalni proračun. Građani obično nemaju dovoljno vremena ili interesa za analiziranje podataka ili proučavanje tema čije je poznavanje nužno kako bi sudjelovali u lokalnom proračunskom procesu. Nužni su podaci često nedostupni ili, ako su dostupni, nerazumljivi su građanima. ${ }^{\mathrm{I}}$ Također, kako tvrde Benito i Bastida (2009), s obzirom na složenost proračuna u modernim gospodarstvima, donositelji političkih odluka uspijevaju sakriti određene porezne terete i obveze vlasti. Često nije u interesu političara da državni ili lokalni proračuni budu jednostavni, pregledni i transparentni.

Prema Wehneru i de Renziu (2012:I) "empirijski dokazi korisnih učinaka fiskalne (proračunske) transparentnosti kreću se od poboljšanih proračunskih ishoda, do nižih troškova zaduživanja i smanjene korupcije.” Transparentnost lokalnih proračuna također omogućava građanima i financijskim tržištima ispravnu procjenu financijskih pozicija i izvedbe lokalnih jedinica te omogućuje aktivnije sudjelovanje građana $\mathrm{u}$ lokalnom proračunskom procesu i pozivanje lokalnih vlasti na odgovornost. $^{2}$

Jesu li proračuni i proračunski procesi u Hrvatskoj otvoreni za javnost i što se može učiniti da budu transparentniji? Kako bismo odgovorili na ta pitanja, tijekom 20Io. smo proveli istraživanje u 33 hrvatska grada koje je obuhvaćalo sljedeće korake.

Prvo smo proveli anketu među gradskim službenicima za informiranje ${ }^{3}$, predstavnicima gradskih uprava, gradskih vijeća i gradskim organizacijama civilnog društva u promatranim gradovima te među predstavnicima Ministarstva financija.

Drugo, u središnjem dijelu istraživanja, osmislili smo i ispunili upitnik koji sadrži 52 pitanja o kvaliteti javno dostupnih informacija predstavljenih u gradskim proračunima i o otvorenosti gradskih proračunskih procesa javnosti. Većina pitanja bavila se informacijama koje su predstavljene u gradskim proračunskim dokumentima i na gradskim službenim internet stranicama. Odgovori na nekoliko pitanja temeljili su se na informacijama koje su prikupljene anketom.

\footnotetext{
${ }^{\mathrm{I}} \mathrm{Npr}$. GONG (2OIO) navodi kako su manje od 50 posto odgovora na upitnik poslan hrvatskim tijelima javne uprave (uključujući županije, općine i gradove) primili na vrijeme i u skladu sa Zakonom o pravu na pristup informacijama te kako su odgovori javnih upravnih tijela građanima često bili samo formalni i nepotpuni, što upućuje na zaključak da građani ponekad mogu ostvariti pristup informacijama samo uz veliki napor.

2 “Transparentnost je prvi korak prema pozivanju lokalnih vlasti na odgovornost zbog načina korištenja javnog novca. Otvoreni proračuni daju snagu. Oni omogućuju ljudima da prosude jesu li njihovi lokalni službenici dobro koristili javna sredstva” (---, 20IO).

${ }^{3}$ Tijela javnih vlasti (uključujući gradske uprave) dužna su imenovati službenu osobu - službenika za informiranje - koji prima i razmatra zahtjeve za pristup informacijama.
} 
Sastavili smo tri verzije indeksa otvorenosti gradskih proračuna (Open City Budget Index, OCBI) temeljenih na upitniku. OCBI-I mjeri kvalitetu javno dostupnih informacija koje su predstavljene $\mathrm{u}$ gradskim proračunima, OCBI-2 kvantificira otvorenost gradskih proračunskih procesa javnosti, dok ukupni OCBI predstavlja zbrojnu mjeru koja uzima u obzir oba područja otvorenosti.

Konačno, angažirali smo "reprezentativnu građanku”, bez znanja o proračunu, da neovisno od ostalih istraživača istraži službene internet stranice analiziranih gradova.

Iako su neki od nalaza ankete korišteni za ispunjavanje upitnika, anketa i opaske reprezentativne građanke služili su nam prvenstveno za bolje razumijevanje proračunskog procesa i za sastavljanje zaključaka i preporuka.

Glavni su nalazi sljedeći. Prvo, proračuni hrvatskih gradova nisu dovoljno transparentni. Prosječni OCBI-I dobiven za sva 33 grada iznosi 57, što znači da smo, u prosjeku, dobili samo 57 posto očekivane kvalitete informacija u proračunskim dokumentima gradova. U tom su području potrebna značajna poboljšanja.

Drugo, proračunski proces u hrvatskim je gradovima prilično transparentan. Prosječan OCBI-2 iznosi 82, što znači da gradovi pružaju 82 posto očekivane otvorenosti proračunskog procesa. Međutim, gradski službenici za informiranje, gradska vijeća i gradske uprave često nisu odgovorili na naše zahtjeve i, nadalje, informacije o gradskim proračunima koje smo dobili izravno od gradskog službenika za informiranje često nisu bile potpune ili su nam pruženi komplicirani odgovori.

Odgovori gradskih vijeća i gradskih uprava na anketu također upućuju na to da je proračunski proces u Hrvatskoj uglavnom transparentan. Kad je riječ o razmjeni dokumenata o gradskim proračunima, većina sudionika zna što se treba učiniti, u kojim rokovima i tko je odgovoran za što. Međutim, postoje neki problemi: (a) kod gradskih uprava i gradskih vijeća, stranka na vlasti obično igra glavnu ulogu dok je oporba samo marginalni igrač, često loše obaviještena i s malo mogućnosti za utjecaj na gradski proračun ili sudjelovanje u gradskom proračunskom procesu; (b) većina građana nije zainteresirana ili nema vremena za sudjelovanje u gradskom proračunskom procesu; i (c) Ministarstvo financija nema dovoljno osoblja i uglavnom je zaokupljeno proračunom središnje države, nema sistematični pristup pitanjima financiranja lokalnih jedinica što komplicira i produljuje postupak razmjene dokumenata između Ministarstva financija i gradskih uprava.

Glavni problemi vezani uz službene internet stranice gradova su: (a) nedostatak jasnog dizajna stranice koji bi omogućio lakše korištenje; (b) nepostojanje izravnih linkova na proračunske dokumente; i (c) velike razlike u opsegu i izgledu predstavljenih proračunskih informacija za različite godine u svakome gradu.

Nakon ovog uvoda, drugi dio članka prikazuje korištene definicije i načine mjerenja transparentnosti proračuna, uključujući i metodologiju. U trećem i četvrtom se dijelu objašnjavaju indeks i rezultati ankete. Članak završava sa zaključcima i preporukama. 


\section{POJMOVI I MJERENJE}

\section{I. DEFINICIJE TRANSPARENTNOSTI PRORAČUNA}

Za potrebe ovog istraživanje možemo definirati transparentnost gradskih proračuna kao mogućnost građana da dobiju informacije o proračunu svoga grada koje su potpune, bitne, točne, pravovremene i predstavljene na razumljiv način. To je spoj dviju definicija koje transparentnost opisuju kao (I) potpuno, pravovremeno i sistematično otkrivanje svih bitnih fiskalnih informacija (OECD, 2002.) i (2) mogućnost svih građana države na pristup informacijama o iznosu raspodijeljenom za različite vrste potrošnje i o prikupljenim prihodima (IBP, 2008.). ${ }^{4}$

Transparentnost gradskih proračuna pokazuje: (I) količinu i kvalitetu informacija predstavljenih javnosti u gradskim proračunskim dokumentima, (2) može li građanin dobiti i razumjeti informacije o gradskim proračunima te (3) mogu li građani vjerovati tim dokumentima.

Usredotočujemo se na mjerenje transparentnosti gradskih proračuna i, do određene mjere, transparentnosti gradskih proračunskih procesa. Pod pojmom transparentnosti gradskih proračunskih procesa zapravo smatramo da svi sudionici - Ministarstvo financija, gradska vijeća, gradske uprave i građani - razumiju što mora biti učinjeno te kada i tko to mora učiniti. ${ }^{5}$

Zapravo, načelo proračunske transparentnosti jedno je od glavnih proračunskih načela u hrvatskom Zakonu o proračunu, a odnosi se na obvezno objavljivanje određenih proračunskih dokumenata $u$ državnom javnom glasilu (za središnju vlast) ili u lokalnom javnom glasilu (za lokalne jedinice). ${ }^{6}$

\subsection{RAZLIČITE MJERE TRANSPARENTNOSTI PRORAČUNA}

Ne postoji jedinstven ili precizan način mjerenja transparentnosti proračuna, međutim vrlo korisne smjernice nalaze se u OECD-ovim Najboljim praksama za transparentnost proračuna (OECD, 2002.), Kodeksu dobrih praksi fiskalne transparentnosti (MMF, 2007.) i Vodiču za upitnik o otvorenosti proračuna: Objašnjenja pitanja i mogući odgovori (IBP, 2OIOa).

Razni istraživači su koristili upitnike i ankete te su temeljem dobivenih odgovora osmislili razne vrste indeksa transparentnosti proračuna (Tablica I). Našli smo samo dva objavljena znanstvena članka o transparentnosti lokalnih proračuna: Boubeta, Santias i Alegre (2010) te Beales i Thompson (2010). U Hrvatskoj smo pronašli šest istraživačkih projekata koji su donekle povezani s transparentnošću proračuna. Jedan se od njih bavi otvorenošću proračuna središnje države (IBP, 2006; 2008; 20Iob), dok se ostalih pet odnosi na transparentnost lokalnih proračuna i provele su ih hrvatske organizacije i

\footnotetext{
${ }^{4}$ Postoje i druge, šire definicije proračunske transparentnosti koje se ne odnose samo na informacije iz proračuna. MMF (2008) koristi pojam fiskalna transparentnost koji definira kao otvorenost prema javnosti o državnim prošlim, sadašnjim i budućim fiskalnim aktivnostima te o strukturama i funkcijama vlade koje određuju fiskalne politike i ishode. Prema Poterbi i von Hagenu (I999:3-4) "transparentan je onaj proračunski proces koji omogućuje jasne informacije o svim aspektima državne fiskalne politike. Proračuni koji sadrže brojne posebne račune i koji ne konsolidiraju sve fiskalne aktivnosti u jednu "bitnu" mjeru nisu transparentni. Proračuni koji su dostupni javnosti i sudionicima u procesu stvaranja politike i koji predstavljaju konsolidiranu informaciju, su transparentni."

${ }^{5}$ Za potrebe našeg istraživanja, gradska uprava obuhvaća gradonačelnika i njegovog zamjenika, kao i gradska upravna tijela.

${ }^{6}$ Prema Zakonu o proračunu (87/o8) sljedeći dokumenti trebaju biti objavljeni: usvojeni proračun, usvojene projekcije, odluka o privremenom financiranju, polugodišnji i godišnji izvještaj.
} 
autori (Maletić, 2006; GONG, 2009; Profeta, 2009; Bratić, 2008 te Antić i Malatestinić, 2010). Samo je u jednom istraživačkom projektu izračunat indeks transparentnosti proračuna - za središnju državu u Hrvatskoj (IBP, 2006; 2008; 2010b).?

\section{TABLICA I.}

Mjere fiskalne/proračunske transparentnosti

\begin{tabular}{|c|c|c|c|}
\hline Autori & Indeks & Uzorak & Metoda \\
\hline $\begin{array}{l}\text { Alesina, Hausmann } \\
\text { i Hommes (I999) }\end{array}$ & $\begin{array}{l}\text { proračunskih } \\
\text { institucija }\end{array}$ & $\begin{array}{l}\text { 2o latinoameričkih } \\
\text { i karipskih država }\end{array}$ & $\begin{array}{l}\text { Dva upitnika koja su obuhvatila deset } \\
\text { karakteristika proračunskih procesa }\end{array}$ \\
\hline $\begin{array}{l}\text { Bastida i Benito } \\
(2007,2009)\end{array}$ & $\begin{array}{l}\text { transparentnosti } \\
\text { proračuna }\end{array}$ & 4I država & $\begin{array}{l}\text { Upitnik koji se temelji na Najboljim } \\
\text { praksama OECD-a }\end{array}$ \\
\hline $\begin{array}{l}\text { Beales i Thompson } \\
\text { (2OIO) }\end{array}$ & $\begin{array}{l}\text { fiskalne } \\
\text { transparentnosti }\end{array}$ & $\begin{array}{l}\text { I34 lokalne jedinice } \\
\text { u Virginiji, SAD }\end{array}$ & $\begin{array}{l}\text { Dostupnost podataka na internet } \\
\text { stranicama lokalnih jedinica koristeći } \\
\text { I6 kriterija na skali od ıoo bodova }\end{array}$ \\
\hline $\begin{array}{l}\text { Boubeta, Santias } \\
\text { i Alegre (2OIO) }\end{array}$ & $\begin{array}{l}\text { fiskalne } \\
\text { transparentnosti }\end{array}$ & $\begin{array}{l}33 \text { galicijskih općina, } \\
\text { Španjolska }\end{array}$ & $\begin{array}{l}\text { Upitnik koji se temelji na tri stupa } \\
\text { MMF-ovog Kodeksa i autorovo } \\
\text { znanje o proračunskim procesima i } \\
\text { stvarnostima lokalnih jedinica }\end{array}$ \\
\hline Hameed (2005) & $\begin{array}{l}\text { fiskalne } \\
\text { transparentnosti }\end{array}$ & 57 država & $\begin{array}{l}\text { Ocjenjivanje praksi sukladno MMF- } \\
\text { ovom Kodeksu }\end{array}$ \\
\hline $\operatorname{IBP}(2002)$ & $\begin{array}{l}\text { transparentnosti } \\
\text { proračuna }\end{array}$ & $\begin{array}{l}5 \text { latinoameričkih } \\
\text { država }\end{array}$ & Anketa \\
\hline $\operatorname{IBP}(2006)$ & $\begin{array}{l}\text { otvorenosti } \\
\text { proračuna }\end{array}$ & preko 80 država & Upitnik \\
\hline $\begin{array}{l}\text { Jarmuzek i sur. } \\
(2006)\end{array}$ & $\begin{array}{l}\text { fiskalne } \\
\text { transparentnosti }\end{array}$ & $\begin{array}{l}27 \text { tranzicijskih } \\
\text { gospodarstava }\end{array}$ & $\begin{array}{l}\text { Anketa relevantnih internet stranica } \\
\text { temeljena na upitniku koji slijedi } \\
\text { MMF-ov Kodeks }\end{array}$ \\
\hline von Hagen (1992) & $\begin{array}{l}\text { fiskalne } \\
\text { transparentnosti }\end{array}$ & 8 europskih država & Upitnik \\
\hline
\end{tabular}

Izvor: IJF, $20 I I$.

Pregled literature pokazuje kako: (I) hrvatski građani nedovoljno sudjeluju u lokalnim proračunskim procesima (Maletić, 2006; Antić i Malatestinić, 2010), (2) hrvatski lokalni proračuni i proračuni središnje države doživljavaju se kao nedovoljno transparentni (GONG, 2009; Profeta, 2008; IBP, 2006, 2008, 2010b), i (3) transparentnost gradskih proračuna moglo bi se mjeriti nekom vrstom indeksa (Tablica I).

Nakon proučavanja literature, odlučili smo provesti vlastito istraživanje transparentnosti proračuna lokalnih jedinica, slijedeći uobičajen pristup u osmišljavanju upitnika. Kako bismo bolje razumjeli proračunski proces, također smo proveli anketu među predstavnicima gradske uprave i vijeća, službenicima za informiranje, organizacijama civilnog društva te u Ministarstvu financija.

\footnotetext{
7 Treba napomenuti da je GONG (2009) za svaki grad i općinu u Hrvatskoj izračunao zbrojni indeks koji se odnosi na opću transparentnost lokalne jedinice uzimajući u obzir:(I) dostupnost javnih informacija o sjednicama gradskih/općinskih vijeća; (2) dostupnost javnih informacija o gradskim/općinskim odlukama, (3) suradnja grada/općine sa civilnim društvom, (4) pridržavanje Zakona o pravu na pristup informacijama, te (5) funkcioniranje grada/općine.
} 


\subsection{METODOLOGIJA MJERENJA}

\subsection{Upitnik}

Ključni je dio istraživanja bilo osmišljavanje upitnika. Prvi dio sadrži 37 pitanja o kvaliteti informacija dostupnih $\mathrm{u}$ pet najvažnijih gradskih proračunskih dokumenata. Sljedećih se I5 pitanja bavi otvorenošću gradskog proračunskog procesa javnosti. ${ }^{8}$

Pitanja I-37, uglavnom temeljena na Istraživanju otvorenosti proračuna IBP-a, bave se javnom dostupnosti najvažnijih proračunskih dokumenata i iscrpnosti informacija koje su u njima predstavljene. Stoga pitamo do koje su razine prikazane različite stavke proračuna: rashodi, prihodi (porezni i neporezni prihodi te dotacije) i potraživanja. Nadalje, provjeravamo jesu li iznosi proračunskih stavki popraćeni odgovarajućim tekstualnim objašnjenjima i opisima.

Pitanja od 38 do 52 temeljena su na GONG-ovom istraživanju GONG (2009) i našoj anketi, čime smo dobili uvid u transparentnost proračunskog procesa i otvorenosti lokalnih jedinica javnosti općenito. Prvo se ocjenjuje suradnja gradskih službenika za informiranje, gradskih vijeća i gradskih uprava kojima smo se tijekom istraživanja obratili za pomoć. Drugo, istražuje se jesu li različite informacije dostupne građanima: važni dokumenti vezani uz gradski proračun (npr. pravila postupanja gradskog vijeća i gradski statuti), popis članova gradskog vijeća i odbora za proračunska pitanja, postupci vezani uz sjednice vijeća, itd.

Odlučili smo se analizirati najnovija izdanja svakog dokumenta koji je bio dostupan u vrijeme istraživanja (travanj 2010.): (a) dokumente prijedloga proračuna za proračunsku godinu 2010.9, (b) dokumente usvojenog proračuna za proračunsku godinu 20Io., (c) polugodišnje izvješće za proračunsku godinu 2009., (d) godišnje izvješće za proračunsku godinu 2007. ili 2008. te (e) proračun za građane za proračunsku godinu 2008. ili 2009. ${ }^{\text {IO }}$

Dva su istraživača neovisno pretražila internet stranice 33 grada, pokušavajući pronaći potrebne dokumente o gradskim proračunima i odgovoriti na pitanja iz upitnika za svaki grad. Istraživači su koristili smjernice koje određuju kako odgovoriti na svako pitanje. U slučaju da se neki od dokumenata o lokalnom proračunu nisu mogli pronaći na službenoj internet stranici grada, obratili smo se gradskoj upravi sa zahtjevom da nam ga pošalje.

Za većinu od 52 pitanja bilo je ponuđeno više odgovora. Na primjer, bile su ponuđene tri mogućnosti odgovora: „svi“, „neki“ i „nijedan“ dok je za pitanja s dva moguća odgovora bilo ponuđeno „da“ i „ne“. Na neka je pitanja trebalo odgovoriti brojem.

\footnotetext{
${ }^{8}$ Više detalja dostupno je u IJF (2OII).

${ }^{9}$ Dokumenti predloženog proračuna su: prijedlog proračuna, prijedlog projekcija i odluke o izvršenju proračuna.

${ }^{10}$ Proračun za građane je netehnička prezentacija namijenjena široj publici.
} 


\subsubsection{Odabir uzorka lokalnih jedinica}

Nakon osmišljavanja upitnika, morali smo odlučiti na koji će se uzorak lokalnih jedinica odnositi analiza. Hrvatska ima 576 lokalnih jedinica (2I županiju, I26 gradova i 429 općina). U tom, pripremnom, dijelu istraživanja transparentnosti lokalnih proračuna, odlučili smo u uzorak uključiti 33 hrvatska grada koji su 200I. preuzeli decentralizirane funkcije. ${ }^{\text {II }}$ Odabrali smo 33 grada jer: (I) njihovi proračuni čine otprilike 56\% proračuna svih gradova i općina i (2) njihovo stanovništvo čini skoro 50\% ukupnog hrvatskog stanovništva. Uzorak je stoga usmjeren prema većim i razvijenijim lokalnim jedinicama.

\section{REZULTATI INDEKSA}

Nakon što je popunjen upitnik za svaki grad, prvi je korak u izradi indeksa brojčano vrednovanje odgovora. Brojčane vrijednosti su a priori dodijeljene određenim odgovorima. Stoga je odgovorima "svi”, "neki” i "nijedan” dodijeljeno I, o,5 odnosno o bodova. Ukoliko su bila ponuđena četiri odgovora, broj dodijeljenih bodova iznosio je I, o,67, o,33 odnosno o.

OCBI-I izračunat je temeljem 37 pitanja o kvaliteti javno dostupnih informacija predstavljenih u pet najvažnijih gradskih proračunskih dokumenata. Zbrajajući bodove za svih 37 pitanja dobili smo “rezultat”. Budući da svako pitanje nosi najviše I bod, moguće je ostvariti 37 bodova. Dijeleći ostvareni rezultat s potencijalnim rezultatom i množeći dobiveno sa Ioo, izračunali smo OCBI-I, koji se može kretati od o do roo.

Analogni postupak primijenjen na pitanja 37-52 daje OCBI-2. Kako bismo izračunali Ukupni OCBI, uzimamo u obzir svih 52 pitanja.

Prema OCBI-I, najbolje je rezultate ostvario Slavonski Brod (79), a najlošiji je Pazin (34). Prosječni OCBII za sva 33 grada iznosi 57 od Ioo, što znači da je, u prosjeku, bilo dostupno oko 57\% očekivane kvalitete informacija $\mathrm{u}$ javno dostupnim gradskim proračunskim dokumentima. ${ }^{\mathrm{I2}}$

Očito je da se mnogo može napraviti kako bi se popravila kvaliteta gradskih proračunskih informacija predstavljenih javnosti. Prvo, iako su dokumenti prijedloga proračuna najvažniji dokumenti u proračunskom procesu, tijekom istraživanja samo su u to gradova bili dostupni na službenim internet stranicama. ${ }^{13}$ Drugo, u pogledu dokumenata prijedloga proračuna i dokumenata usvojenog proračuna postoje sljedeće najvažnije razlike: 80 posto gradova ne nudi tekstualne opise (objašnjenja) raznih prihoda i rashoda prema ekonomskoj klasifikaciji; više od dvije trećine gradova ne pruža informacije o

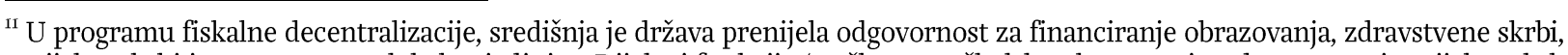
socijalne skrbi i vatrogastva na lokalne jedinice. Dijelovi funkcija/troškova, za školsko obrazovanje, zdravstvenu i socijalnu skrb decentralizirani su na županije, 32 grada i Grad Zagreb, dok redovitu djelatnost vatrogastva financira I26 općina/gradova.

${ }_{12}$ Slučajno, rezultat Hrvatske $u$ istraživanju IBP-a Open Budget Index za 20IO. (koji predstavlja transparentnost proračuna hrvatske središnje države) također je iznosio 57\% (vidjeti Bađun i Urban, 20Io).

${ }^{13}$ U skladu s tim, kontaktirali smo gradske uprave iz preostala 23 grada i zatražili da nam pošalju dokumente prijedloga proračuna. Iz jednog smo grada dobili tiskani primjerak dokumenata prijedloga proračuna. Jedanaest gradova nije poslalo dodatne informacije o dokumentima prijedloga proračuna. Iz preostalih II gradova nas je njihov gradski službenik za informiranje obavijestio kako dokumenti prijedloga proračuna postoje, no nisu nam poslali dokument. Saopćili su nam kako su dokumenti prijedloga proračuna sadržajno identični dokumentima usvojenog proračuna, navodeći to kao razlog zašto dokumenti prijedloga proračuna nisu bili dostupni na službenim internet stranicama tih gradova.
} 
rashodima prema funkcijskoj klasifikaciji; 85\% gradova ne uključuje makroekonomske prognoze na kojima se temelje projekcije proračuna. Nadalje, samo 20 posto gradova izrađuje proračun za građane. ${ }^{I 4}$ Prema indeksu OCBI-2, najbolje su rezultate ostvarili Karlovac i Labin (IOO), a najslabije Vinkovci (47). Prosječna otvorenost gradskih proračunskih procesa javnosti iznosi 82 posto. Rezultati za otvorenost gradskih proračuna prema indeksu OCBI-2 su puno bolji od onih temeljem indeksa OCBI-I: samo 5 gradova ima rezultate indeksa OCBI-2 niže od 75, dok je samo jedan grad postigao rezultati veći od 72 za indeks OCBI-I.

Možemo zaključiti kako su proračunski procesi u većini gradova iznimno otvoreni javnosti, no još uvijek ima mjesta za poboljšanja. Stoga bi, na primjer, službenici za informiranje, gradske uprave i gradska vijeća trebali odgovarati na zahtjeve građana za pristupom informacijama, a dnevni redovi sjednica gradskih vijeća bi trebali biti dostupni na službenim internet stranicama gradova prije održavanja sjednica. ${ }^{15}$

Najveći problem vezano uz indeks OCBI-2 je bio relativno slab odaziv gradskih službenika za informiranje, gradskih vijeća i gradskih uprava na naše ankete. Prema Zakonu o pravu na pristup informacijama, sve informacije koje tijela javne vlasti posjeduju, kojima raspolažu ili koja nadziru moraju biti dostupne zainteresiranim osobama. Tijela javne vlasti (uključujući gradske uprave i gradska vijeća) dužna su odrediti službenu osobu, npr. službenika za informiranje, čiji je glavni zadatak primanje i razmatranje pojedinačnih zahtjeva za pristup informacijama. Gradski službenik za informiranje mora odgovoriti na postavljene zahtjeve u roku 15 dana, a informacija koju pruža mora biti potpuna i točna.

Međutim, tijekom istraživanja poslali smo ankete gradskim službenicima za informiranje 3. svibnja 2010., no nakon I5 dana je stopa odaziva bila vrlo niska (oko Io posto). Nakon što smo nekoliko puta podsjetili gradske službenike za informiranje, do 26. srpnja je ukupni odaziv bio 58 posto (odgovorilo je I9 od 33 grada). Nadalje, od 19 gradova čiji su gradski službenici za informiranje odgovorili na anketu, u I2 gradova nismo dobili potpune ili točne podatke. Ti su službenici potvrdili postojanje određenih dokumenata, no unatoč našim zahtjevima, nisu nam ih poslali niti su nam objasnili gdje ih možemo naći (npr. popis povlaštenih korisnika stanova u vlasništvu grada ili kriterij raspodjele donacija iz gradskih proračuna). ${ }^{16}$

Ukupni indeks OCBI opisuje kvalitetu informacija u gradskim proračunima i otvorenost gradskog proračunskog procesa javnosti. Temelji se na svih 52 pitanja iz upitnika. Najbolji je rezultat ostvario Slavonski Brod (82), a najlošiji Šibenik (45). Prosječni OCBI iznosi 65 od mogućih Ioo bodova što znači

\footnotetext{
${ }^{14}$ Slični problemi postoje u pogledu transparentnosti središnjeg proračuna, npr. nepostojanje proračuna za građane (vidjeti Bađun i Urban, 20I0).

${ }^{15}$ Tijekom istraživanja, dnevni redovi za sjednice gradskih vijeća bili su prije sjednica dostupni na internet stranicama $u$ samo 24 od 33 grada.

${ }^{16}$ Međutim, treba naglasiti da otvorenost prema autorima ove ankete ne ukazuje nužno na istu razinu otvorenosti prema drugim građanima jer nismo skrivali činjenicu da provodimo istraživanje.
} 
da su nam gradovi u prosjeku pružili oko $65 \%$ očekivane kvalitete informacija u svojim proračunima i otvorenosti gradskih proračunskih procesa javnosti. ${ }^{17}$

\section{SLIKA I.}

Ukupni OCBI

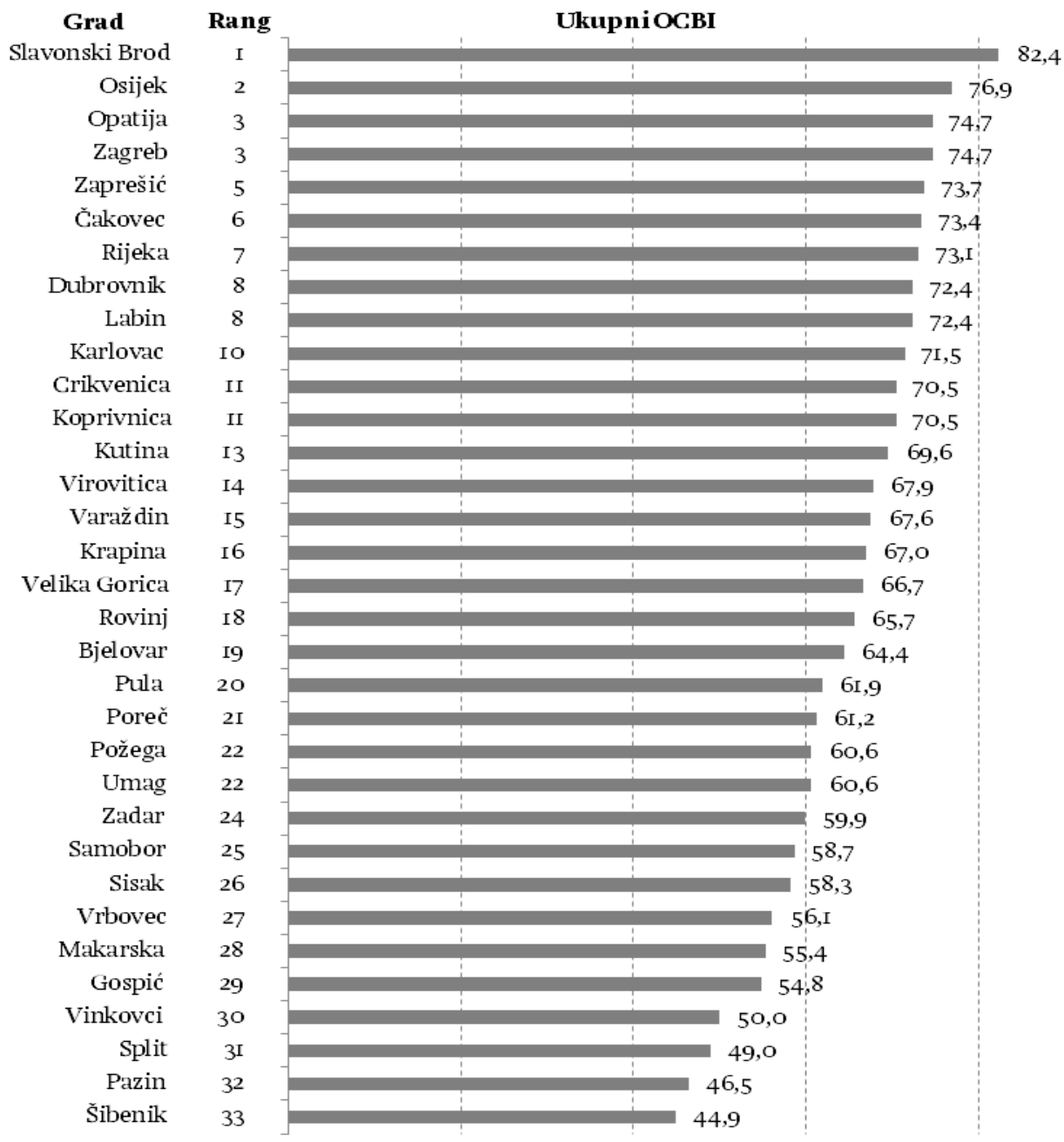

Izvor: IJF, 2OII.

Razlika između gradova koji su ostvarili najbolje i najslabije rezultate manja je od 50\%, što se čini umjereno visokom u usporedbi s IBP-ovim Indeksom otvorenosti proračuna gdje je razlika između države s najboljim i najlošijim rezultatima iznosila više od 90\% (IBP, 2OI2b). Međutim, razlika bi zasigurno bila mnogo veća da smo istraživali sve gradove i općine u Hrvatskoj jer je ukupna transparentnost veća u gradovima nego u općinama (GONG, 2009).

\section{REZULTATI ANKETE}

Od svibnja do srpnja 20Io. proveli smo anketu među gradskim službenicima za informiranje,

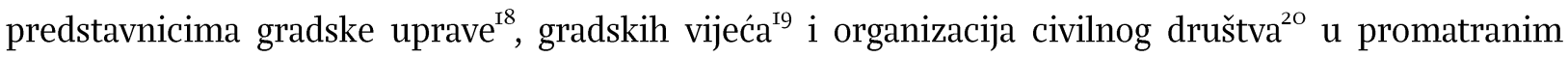

\footnotetext{
${ }^{17}$ Ukupni OCBI u dobroj je korelaciji ( $\left.\rho=0.6\right)$ s GONG-ovim indeksom (vidjeti bilješku 8) kojim je mjerena opća transparentnost hrvatskih lokalnih jedinica (GONG, 2009).

${ }^{18}$ Voditelji financijskih odjela.
} 
gradovima te među predstavnicima Ministarstva financije. Poštom smo ispitanicima poslali preko dvjesto obrazaca.

Glavna je svrha ankete bila stjecanje boljeg uvida $u$ gradske proračunske procese temeljem čega bismo došli do zaključaka i ispravno protumačili rezultate OCBI indeksa. Prvenstveno smo željeli saznati što ispitanici misle o pitanjima kao što su: (I) Je li gradski proračunski proces transparentan? (2) Razumiju li gradske dokumente o proračunu? (3) Što je najveći problem u razumijevanju dokumenata o proračunu? te (4) Što se može učiniti da gradski proračuni postanu transparentniji? ${ }^{21}$ Anketa nije bila strukturirana tako da omogući usporedbu rezultata s rezultatima OCBI. Nadalje, nismo primili odgovore na anketu od svakog grada. Na anketu je odgovorilo 61\% predstavnika gradskih uprava, 58\% gradskih službenika za informiranje, $52 \%$ organizacija civilnog društva, $39 \%$ predstavnika gradskih vijeća te $28 \%$ predstavnika Ministarstva financija.

\section{I. POSTUPAK RAZMJENE DOKUMENATA O PRORAČUNU IZMEĐU GRADSKIH UPRAVA I GRADSKIH} VIJEĆA

Većina anketiranih predstavnika gradskih vijeća i gradskih uprava smatra kako je postupak međusobne razmjene dokumenata o proračunu transparentan (slika 2). Ti su ispitanici odgovorili da znaju što treba napraviti, koji su rokovi i kakve obveze razni sudionici imaju u postupku razmjene dokumenata o proračunu između gradskih uprava i gradskih vijeća.

\section{SLIKA 2.}

Transparentnost postupka razmjene dokumenata o proračunu između gradskih uprava i gradskih vijeća (\%)

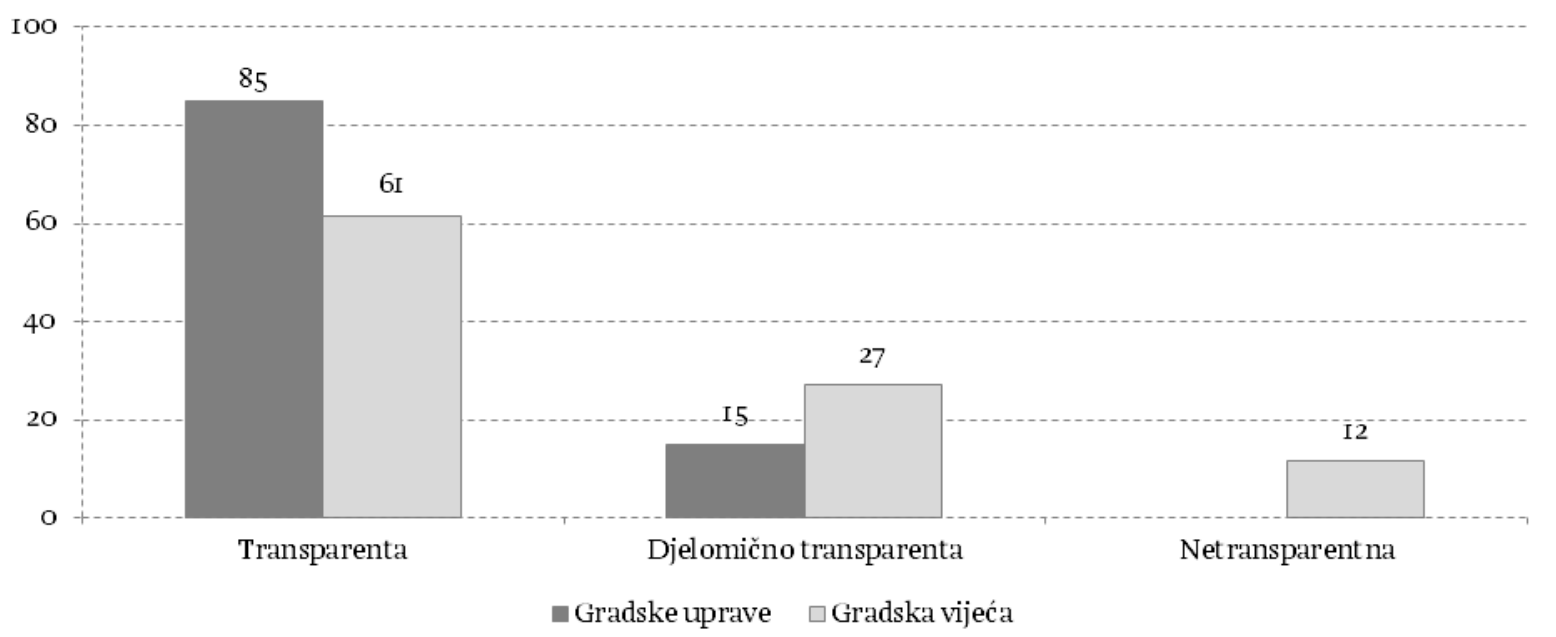

Izvor: IJF, 2011.

\footnotetext{
${ }^{19}$ Jedan iz stranke na vlasti/vladajuće koalicije i drugi iz oporbe.

${ }^{20}$ Naša je ideja bila da se uključe organizacije civilnog društva iz različitih područja financiranja lokalnih jedinica, npr. kulture, sporta, zaštite okoliša, zdravstvene skrbi. Prvi je korak bio odabrati uzorak za svaki grad koji se sastoji od tri područja financiranja koja su primila najveće iznose sredstava iz gradskih proračuna 2007. Za svako od ta tri područja odabrali smo gradsku organizaciju civilnog društva koja je primila najveći iznos sredstava iz gradskog proračuna. U odabiru uzorka, pomogao nam je Vladin ured za suradnju s nevladinim udrugama. Unatoč početnom cilju ispitivanja samo jedne organizacije civilnog društva u svakome gradu, ankete su poslane dvjema nasumično odabranim organizacijama civilnog društva u svakome od gradova, kako bi se povećala vjerojatnost odgovora.

2I Cjelovita anketa i rezultati dostupni su na http://www.ijf.hr/hr/istrazivanja/dovr-353-ena-istrazivanja/540/200620I0/indeks-otvorenosti-proracuna-33-hrvatska-grada/168/.
} 
Čini se da su u svim gradovima predstavnici gradskih uprava bolje obaviješteni o tom procesu od predstavnika gradskih vijeća. Mnogi se predstavnici gradskih vijeća žale na previše improvizacije i podržavaju opće mišljenje da se transparentnost u postupku razmjene dokumenata o gradskim proračunima može popraviti te da cijeli sustav može biti učinkovitiji. Na primjer, $u$ šest je gradova prošlo manje od osam dana otkad su predstavnici gradskih vijeća primili dokumente prijedloga proračuna za 20Io. godinu do usvajanja predloženog proračuna. Pitanje je jesu li u tim gradovima predstavnici gradskih vijeća uopće imali priliku u tako kratkom vremenu učinkovito analizirati dokumente prijedloga proračuna za 20Io. godinu koje su pripremila gradska vijeća te jesu li imali priliku bilo kako utjecati na sami postupak usvajanja proračuna.

\subsection{POSTUPAK RAZMJENE DOKUMENATA O PRORAČUNU IZMEĐU GRADSKIH UPRAVA I MINISTARSTVA FINANCIJA}

Većina predstavnika gradskih uprava smatra da je postupak razmjene dokumenata o proračunu između gradskih uprava i Ministarstva financija transparentan, dok svi predstavnici Ministarstva financija smatraju kako je taj postupak djelomično transparentan (Slika 3). ${ }^{22}$

\section{SLIKA3.}

Transparentnost postupka razmjene dokumenata o proračunu između gradskih uprava $i$ Ministarstva financija (\%)

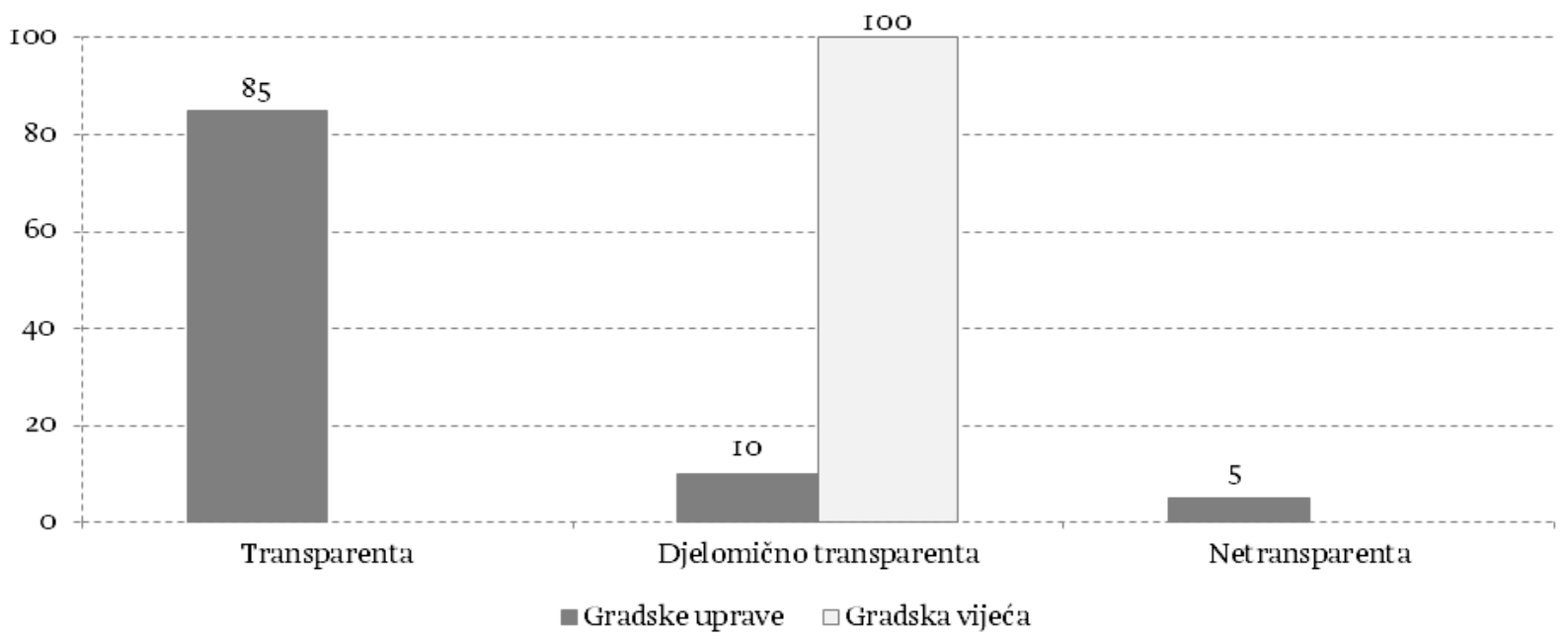

Izvor: IJF, 2011.

Ipak, neki su predstavnici gradskih uprava prigovorili Ministarstvu financija na nemarnom radu, sugerirajući da se Ministarstvo ne pridržava rokova za dostavu dokumenata gradskim upravama te da je zaokupljeno središnjom državom i stoga obraća premalo pozornosti lokalnim jedinicama kao i da ignorira i ne odgovara na upite gradskih uprava.

Ministarstvo financija također je istaknulo neke od najvažnijih razloga zašto razmjena gradskih proračunskih dokumenata i komunikacija između Ministarstva financija i gradskih uprava nisu potpuno transparentni:

${ }^{22} \mathrm{Na}$ ovo je pitanje odgovorio 2I ispitanik iz gradskih uprava i dva iz Ministarstva financija. 
- Ministarstvo financija ima nesistematičan pristup pitanjima financiranja lokalnih jedinica;

- česte su izmjene propisa u relativno kratkim razdobljima, što ima za posljedicu propuste i pogreške te brojne izmjene i dopune koje kompliciraju i produljuju postupak razmjene dokumenata između Ministarstva financija i gradskih vijeća;

- zakoni su komplicirani i teško razumljivi, a njihova tumačenja ne olakšavaju primjenu. Ponekad postoji više tumačenja istog pitanja, što zbunjuje lokalne jedinice;

- lokalne su jedinice ponekad slabo opremljene (tehnički i kadrovski);

- postoji previše lokalnih jedinica (576 gradova i općina); te

- Ministarstvo financija $\mathrm{u}$ odjelu za financiranje lokalnih jedinica zapošljava samo sedam službenika, što je premalo.

Gradske uprave zbog navedenih problema vezanih uz proces razmjene dokumenata između Ministarstva financija i gradskih uprava često kasne s podnošenjem izvješća Ministarstvu financija. Na primjer, iako je Zakonom o proračunu u članku Iı2. određeno da lokalna izvršna tijela trebaju dostaviti godišnja izvješća Ministarstvu financija i Državnom uredu za reviziju u roku od I5 dana otkad ih usvoji lokalno predstavničko tijelo, od 8. ožujka 20ıo. samo je 379 od 576 lokalnih jedinica (tj. 66\%) dostavilo Ministarstvu financijska godišnja izvješća za 2008. Problem je u tome što je zakonski rok u kojem lokalna izvršna tijela moraju podnijeti godišnja izvješća lokalnim predstavničkim tijelima propisan, ali nije propisan rok do kojeg lokalno predstavničko tijelo mora usvojiti godišnje izvješće. Zbog toga se može dogoditi da neka gradska vijeća ne usvoje godišnje izvješće te ga stoga ne pošalju Ministarstvu financija.

\subsection{GRADSKE ORGANIZACIJE CIVILNOG DRUŠTVA (PREDSTAVNICI GRADANA)}

Prema našoj anketi malo manje od 50\% organizacija civilnog društva izjavilo je da vrlo dobro razumiju gradske proračunske dokumente koje koriste, a 41\% tvrdi da te dokumente razumiju djelomično. Većina organizacija civilnog društva istaknula je kako u cijelosti ili djelomično razumiju samo one dijelove gradskih proračunskih dokumenata koji se odnose na njihove organizacije.

Većina je organizacija civilnog društva navela kao glavni nedostatak u korištenju gradskih proračunskih dokumenata nerazumljivu pravnu terminologiju, česte izmjene proračunskih klasifikacija i nedostatak vremena. Očito, gradske organizacije civilnog društva ne koriste gradske proračunske dokumente jako često i stoga trebaju jednostavna pojašnjenja pravne terminologije, više osnovnih informacija o gradskim proračunima i proračunskom procesu (npr. što je gradski proračun i koje stavke obuhvaća), jednostavna pojašnjenja izmjena proračunskih klasifikacija i jednostavne smjernice kako bi organizacije civilnog društva i građani mogli sudjelovati u proračunskom procesu. 


\section{ZAKLJUČCI I PREPORUKE}

Ovo istraživanje predstavlja prvi pokušaj mjerenja otvorenosti lokalnih proračuna u Hrvatskoj. Rezultat istraživanja su indeksi OCBI-I, OCBI-2 i ukupni OCBI, kojima se rangiraju 33 hrvatska grada prema kvaliteti informacija o proračunu i otvorenosti proračunskog procesa javnosti. Prosječni ukupni OCBI označava da su, u prosjeku u 20I0., 33 hrvatska grada pružila 65\% očekivane kvalitete informacija o proračunu i otvorenost proračunskog procesa javnosti.

Rezultate istraživanja treba tumačiti s oprezom. Moguće je da naši indeksi ne obuhvaćaju sve bitne kriterije mjerenja transparentnosti lokalnih proračuna te da su do neke mjere neizbježno sastavljeni arbitrarno. Drugi se problem mjerenja transparentnosti gradskih dokumenata o proračunu odnosi na prikupljanje podataka. Moguće je da neka bitna informacija postoji, ali je mi nismo mogli naći jer službene internet stranice nekih gradova nisu pregledne i na njima je stoga teško pronaći podatke (npr. službena internet stranica Vinkovaca u vrijeme provođenja našeg istraživanja). Nadalje, podaci i linkovi na službenim se gradskim internet stranicama često mijenjaju.

Kao zaseban problem, trebali bismo biti svjesni argumenta Benita i Bastide (2009) da, iako formalna pravila i postupci u lokalnim jedinicama postoje, moguće je da se u praksi ne primjenjuju. Na primjer, gradskim propisima može biti određeno da građani mogu prisustvovati sjednicama gradskih vijeća, ali u praksi ne mogu ostvariti to pravo.

Rezultati istraživanja mogu utjecati na sve sudionike gradskih proračuna i proračunskih procesa. Pokazuju da:

- se gradske uprave trebaju koncentrirati na pravovremeno objavljivanje najvažnijih dokumenata, po mogućnosti na službenim internet stranicama koje trebaju redovito ažurirati i poboljšati preglednost, objavljivati proračun za građane, organizirati javne rasprave, povećati ulaganja u obrazovanje svojih članova, poticati građane i biti im dostupniji.

- Iako su druga violina gradskim upravama, gradska vijeća trebaju zahtijevati od gradskih uprava puno i ispravno te pravovremeno i razumljivo otkrivanje svih bitnih informacija o gradskim proračunima. Trebali bi temeljito proučiti dokumente o proračunu te raspraviti i utjecati na proračunsku politiku, pozivati gradsku upravu na odgovornost i zahtijevati mogućnosti za profesionalni razvoj.

- Ministarstvo financija trebalo bi bolje surađivati i koordinirati rad s gradskim upravama, bolje organizirati svoje odjele zadužene za suradnju s gradskim upravama te izvršiti pritisak na Vladu da smanji broj lokalnih jedinica. Trebalo bi smanjiti učestalost izmjena zakona, pravilnika i proračunskih klasifikacija ili barem bolje izvještavati gradske uprave i uključiti ih u pripremanje tih izmjena, pravovremeno im slati sve dokumente i bez odgađanja odgovarati na njihove upite.

- Iako se smatra da su mediji najvažniji u nezavisnom nadzoru gradskih proračuna, trebali bi biti još više angažirani u gradskom proračunskom procesu kako bi pružili pravovremene informacije građanima o ključnim događajima vezanim uz proračun.

- Građani bi se trebali obrazovati i zahtijevati pravovremene, bitne, jednostavne i razumljive informacije od gradskih uprava te više sudjelovati u lokalnom proračunskom procesu. 
Konačno, treba napomenuti da informacije koje smo prikupili u ovome istraživanju mogu poslužiti kao osnova za zaključke o daljnjim važnim temama istraživanja kao na primjer zašto su neki gradovi transparentniji od drugih ili koje prednosti donosi veća transparentnost. No, u ovom je trenutku naša pažnja usmjerena na definiranje istraživačke metodologije koju je moguće unaprijediti prema potrebama za buduća istraživanja. Nadalje, kako bismo pribavili više pouzdanih saznanja, u istraživanju treba koristiti veći i reprezentativniji uzorak lokalnih jedinica.

S engleskog prevela

Irena Klemenčić 


\section{LITERATURA}

---, 20Io. South Africa in top five for openness. Dostupno na: [http://uk.oneworld.net/article/view/162140/1/5795].

Alesina, A. [et al.], 1999. "Budget institutions and fiscal performance in Latin America". Journal of Development Economies, 59 (2), 253-273. doi: 10.1016/SO304-3878(99)OoOI2-7

Antić, T. i Malatestinić, I., 2oro. Udruga općina u Republici Hrvatskoj. Istraživački izvještaj: Smanjenje percepcije korumpiranosti u lokalnoj samoupravi “SPECULAS”. Dostupno na: [http://www.udrugaopcina.hr/hrv/projekti/projekt.php?ID=IO70].

Bađun, M. i Urban, I., 201o. “Croatia's Score on Open Budget Index 2010” Press Release, No. 26. Dostupno na: [http://www.ijf.hr/eng/releases/26.pdf].

Bastida, F. i Benito, B., 2007. "Central Government Budget Practices and Transparency: An international Comparison”. Public Administration, 85 (3), 667-716. doi: IO.IIII/j.I4679299.2007.00664.X

Beales, J. i Thompson, M. W., 20Io. Government Transparency in Virginia: How Localities Compare. Dostupno na: [http://www.thomasjeffersoninst.org/pdf/articles/Govt Transparency LocalGov.pdf].

Benito, B. i Bastida, F., 20o9. "Budget Transparency, Fiscal Performance and Political Turnout: An International Approach”. Public Administration Review, 69 (3), 403-4I7. doi: IO.IIII/j.I5406210.2009.01988.X

Boubeta, A. S., Santias, F. R. i Alegre, J. G., 20ro. Budget Transparency in Local Government: Empirical Analysis on a Sample of 33 Galician Municipalities. Dostupno na: [http://www.um.es/dphacienda/eep2010/comunicaciones/eep2010-65.pdf].

Bratić, V., 2008. Odlučivanje o lokalnim proračunima: između sna i jave. Zagreb: Institut za javne financije; Friedrich Ebert Foundation.

GONG, 2009. Istraživački izvještaj- LOTUS- lokalna odgovorna i transparentna uprava $i$ samouprava. Dostupno na: [http://www.gong.hr/page.aspx?PageID=185].

GONG, 20Io. Analiza službenog izvješća o provedbi Zakona o pravu na pristup informacijama (ZPPI) za 2009. godinu. Dostupno na: [http://www.gong.hr/news.aspx?newsID=3373\&pageID=I].

Hameed, F., 2005. "Fiscal Transparency and Economic Outcomes". IMF Working Paper, WP/o5/225. Washington: International Monetary Fund.

IBP, 2002. Index of Budget Transparency in Five Latin American Countries. Dostupno na: [http://www.internationalbudget.org/resources/LAbudtrans.pdf].

IBP, 2006. More Public information needed to Hold Government to Account. Dostupno na: [http://internationalbudget.org/wp-content/uploads/20II/o6/SummaryReportenglish.pdf].

IBP, 2008. Open Budget. Transform Lives. The Open Budget Survey 2008. Dostupno na: [http://internationalbudget.org/wp-content/uploads/20II/o6/2008FinalFullReportEnglishi.pdf].

IBP, 2oroa. Guide to the Open Budget Questionnarie: An Explanation of the Questions and the Response Options. Dostupno na: $\quad$ http://internationalbudget.org/wpcontent/uploads/GuideOBI2OIO English.pdf.

IBP, 20Iob. Open Budget. Transform Lives. The Open Budget Survey 20Io. Dostupno na: http://internationalbudget.org/wp-content/uploads/20II/o6/20IO Full Report-English.pdf].

IJF, 20II. Measuring Local Units' Transparency and Accountability: The Croatian Open Local Budget Index. Dostupno na: [http://www.ijf.hr/eng/conferences/measuring-local-units-transparency-andaccountability-the-croatian-open-local-budget-index/362/].

IMF, 2007. Code of Good Practices on Fiscal Transparency. Dostupno na: [http://www.imf.org/external/np/pp/2007/eng/o5I507c.pdf].

IMF, 2009. How Does the IMF Encourage Greater Fiscal Transparency?. Dostupno na: [http://www.imf.org/external/np/exr/facts/fiscal.htm].

IMF, 20Io. Reports on the Observance of Standards and Codes (ROSCs). Dostupno na: [http://www.imf.org/external/NP/rosc/rosc.aspx?sortBy=Topic\&sortVal=Fiscal\%2oTransparency].

Jarmuzek, M. [et al.], 20o6. Fiscal Transparency in Transition Economics, Studies and Analyses. Warszaw: Center for Social and Economic Research. 
Maletić, I., 2006. “Subnational Budget Watch on Croatia: Is Anybody There?” in: K. Ott, ed. Making Public Finance Public: Subnational Budget Watch in Croatia, Macedonia and Ukraine. Budapest: Local Government and Public Service Reform Initiative. Dostupno na: [http://ggi.osi.hu/publications/2006/338/Making Public Finance Public 2.pdf].

OECD, 2002. OECD Best Practices for Budget Transparency. Dostupno na: [http://www.oecd.org/dataoecd/33/13/1905258.pdf].

Poterba, J. i von Hagen, J., 1999. Fiscal Institutions and Fiscal Performance. Chicago: University of Chicago Press.

Profeta, A., 20o8. Porazni rezultati istraživanja korupcije u 8 hrvatskih gradova. Dostupno na: http://www.monitor.hr/clanci/porazni-rezultati-istrazivanja-korupcije-u-8-hrvatskihgradova/IO2 $/$.

Urban, I. i Bađun, M., 2009. Open Budget Index 2008- Small Advances Made in the Accessibility of Information about Croatian Public Finance. Dostupno na: [http://www.ijf.hr/eng/releases/8.pdf, http://www.ijf.hr/osvrti/8.pdf].

von Hagen, J., 1992. "Budgeting procedures and fiscal performance in the European Community”. EEC Economics Papers, No. 96.

Wehner, J. i de Renzio, P., 2012. „Citizens, Legislators, and Executive Disclosure: The Political Determinants of Fiscal Transparency“. Dostupno na: [http://internationalbudget.org/wpcontent/uploads/IBP-Working-Paper-3-Political-Determinants-of-Fiscal-Transparency.pdf].

Zakon o pravu na pristup informacijama, NN 172/O3. Zagreb: Narodne novine.

Zakon o proračunu, NN 87/o8. Zagreb: Narodne novine. 